DOI: $10.4274 /$ tpa.46.38

\title{
Ergenlik çağında kanserler
}

Malignancies in adolescence

İnci Ylldz

İstanbul Üniversitesi Cerrahpaşa Tıp Fakültesi, Pediatrik Hematoloji-Onkoloji Bilim Dall, istanbul, Türkiye

\section{Özet}

Son 30-40 yılda çocuk kanserlerinde büyük aşamalar kaydedilmiş ve çok yüksek sağkalım oranlarına ulaşılmıştır. Ergenlik döneminde görülen kanserlerin kendine has özellikleri vardır. Bu dönemde görülen kanser tipleri farklı olduğu gibi elde edilen sağkalım oranları da farkıdır. Bunda ergenin fiziksel yapısı kadar psikolojik etmenler de rol oynamaktadır. Çocukluk yaşına göre daha çok sayıda ergen kanser tanısı almaktadır. Ergende lösemi ve sarkomların iyileşme oranları çocuklara göre daha düşüktür. Bu yaş grubunda Hodgkin hastalığı ve kemik tümörleri de daha sık gözlenmektedir. Ergene konusunda deneyimli, psikolojik destek ve eğitim sağlayacak bir ekibin tedavisi başarıyı artırmaktadır. (Türk Ped Arş 2011; 46 Özel Sayı: 68-9)

Anahtar sözcükler: Kanser, ergen, tedavi, sağ kalım

\section{Summary}

Great progresses were achieved in chilhood cancers in the last 30-40 years and high survival rates are obtained. Cancer in adolescents have special features and survival rates. This is because of adolescent's physical status and psychological needs. More adolescents are diagnoseed with cancer in comparison to children. The overall survival and cure rates of leukemias and sarcomas in the adolescent period are much lower than childhood. Hodgkin's disease and bone tumors are more frequent in adolescents. Success in the treatment of adolescent cancers will increase with the treatment of these cases in specialised centers with good medical, psychologic and educative staff. (Turk Arch Ped 2011; 46 Suppl: 68-9)

Key words: Canser, adolescent, treatment, survival

\section{Giriş}

Son 30-40 yılda çocuk kanserlerinde büyük aşamalar kaydedilmiş ve çok yüksek sağkalım oranlarına ulaşılıışır (1). Lösemilerde, böbrek tümörlerinde, lenfomalarda \%80-90 lık yaşam oranları sağlanır olmuştur. Bu başarı yeni ilaçların bulunuşu, kombine ilaç protokolleri ile çok yoğun kemoterapilerin verilişi, radyoterapi, çocuk cerrahı ile pediatrik onkoloji uzmanının bir ekip zihniyeti içinde ortak protokoller uygulamaları ve destek tedavilerin gelişmesi ile olmuştur. Ergenlik döneminde görülen kanserlerin kendine has özellikleri vardır. Ergen ve genç erişkinde görülen kanser tiplerinin sıklığı farklı olduğu gibi, elde edilen sağkalım oranları da farklıdır. Bunda ergenin fiziksel yapısı etkili olduğu gibi, psikolojik etmenler de rol oynamaktadır. Ayrıca 15-25 yaşlar arasında çocukluk yaşına göre daha çok sayıda ergen kanser tanısı almaktadır (2). Bu yaş grubunda özellikle lösemi ve sarkomların iyileşme oranları çocuklara göre daha düşüktür. Herşeyi ile özel bu yaşlarda kanser tedavilerinin deneyimli bir ekip ile özel ergen kanseri kliniklerinde yapılması önerilmektedir. Ergenlerde yılda milyonda 200 yeni kanser olgusu beklenmektedir. Çocukluk çağında bu oranın yarısı kadar olgu gözlenir. 
Aşağıdaki şekilde Türk Pediatrik Onkoloji Grubunun yaptığı tümör istatistik verileri görülmektedir (3). Burada son yedi yılda bildirilmiş olan ergen tümörleri verilmiştir. $\mathrm{Bu}$ yaş grubunda daha az sayıda tümör bildirilmiş oluşunu olguların bir kısmının erişkin onkoloji uzmanlarına gitmesi ile açıklayabiliriz.

Bu yaş grubunda kanser dağılımları Şekil 2' de görülmektedir. Bu dağllım ABD istatistiksel verileridir (4):

Çocukluk çağından farklı olarak lösemiler oldukça düşük oranda olup, Hodgkin lenfoma, germ hücreli tümör ve kemik tümörü sıklığı artmaktadır.

Çocukta ve ergenlerde henüz kanserin nedeninini bilmiyoruz. Az sayıda genetik geçişli kanser olsa da çevresel etkenlerin belli kanser tiplerine yatkınlık ile birlikte etkili olduğu tahmin ediliyor. Örneğin; annenin gebeliğinde "dietilstilbestrol" kullanmasının, ergen kızlarda vajina ya da

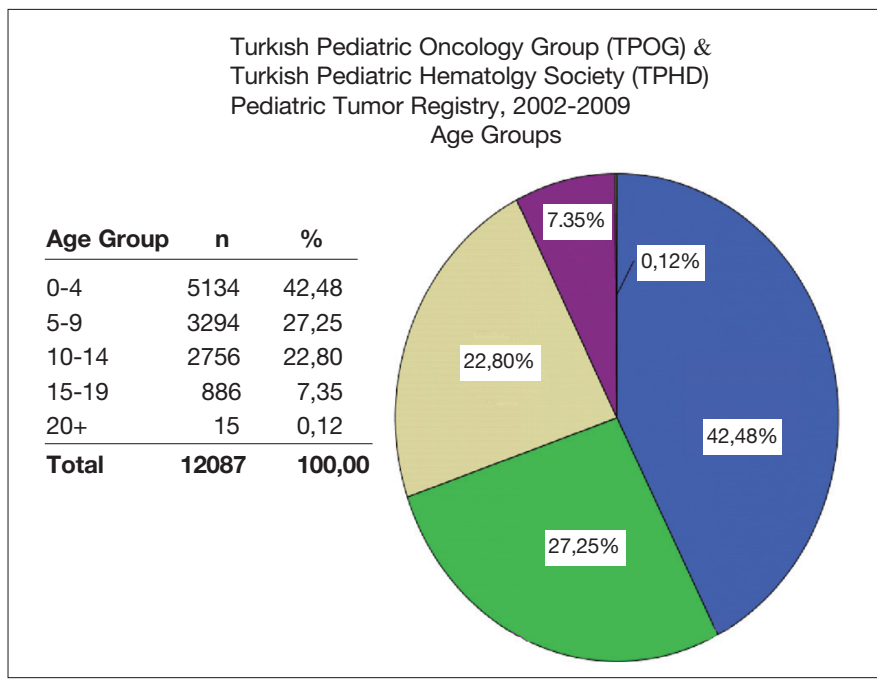

Şekil 1. Türk Pediatrik Onkoloji Grubu istatistikleri

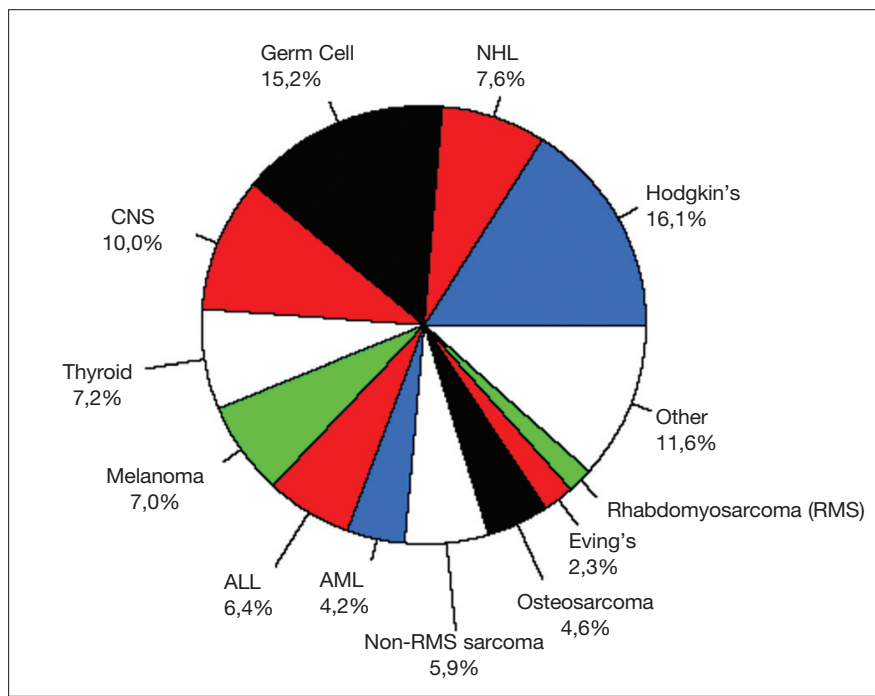

Şekil 2. ABD istatistiksel verileri serviks kanseri yaptığını, erken çocukluk döneminde kanser nedeniyle kemoterapiye ek olarak ışın tedavisi uygulanmasının ergenlik ve genç erişkin döneminde ikincil kanserlere sebep olabildiği biliniyor. Ergende Hodgkin lenfoma riski, kardeşinde aynı hastalık olanlarda, normal popülasyona göre $7 \mathrm{kez}$ fazladır. Epstein-Barr virus de etyolojide rol oynamaktadır (5). Uganda'da, Nijerya'da Kaposi sarkomu sıklığı artmıştır. Nedeni de AIDS'dir. Ergende Kaposi sarkomu kızlarda daha fazladır. $\mathrm{Bu}$ durum kızların daha erken yaşta cinsel etkinlik yaşaması ve daha yüksek oranda HIV taşıması ile açıklanabilir (5). Hepatosellüler karsinom olgularının çoğunluğu Hepatit B taşıyıcılığının yüksek olduğu doğu Asya'da karşımıza çıkmaktadır. Aşılamanın yaygınlaşmasının bu oranı düşüreceği umulmaktadır.

İnmemiş testis ve testislere travma da testis tümörü oluşumu için risk etkenleridir. Geç püberte testis tümörlerine karşı koruyucudur.

Tiroid bezi, radyasyona çok duyarlıdır ve tiroid kanseri için en yüksek risk, erken yaşta radyasyonla karşılaşılmasıdır. Bu risk radyasyon sonrası 40 yıl boyunca sürer. 1986 yılındaki Chernobyl nükleer reaktör kazasında doğu Avrupa'da çok sayıda küçük çocuk radyasyona maruz kalmıştır. Kazadan 10 yıl sonra bu çocuklarda tiroid kanseri 7-10 kat artmıs bulunmustur. Ayrıca guatr ve selim tiroid nodül ve adenomlarının tiroid kanseri için güçlü risk faktörü olduğu bilinmektedir.

Erken yaşta ultraviyole ışınlara şiddetli, ama aralıklı maruz kalma genç yaşta melanom riskini arttııı (6).

Çevresel karsinojenlerin (tütün, güneş ışını, diyet gibi) somatik hücrelerde DNA hasarı yaparak kanser oluşturması yaşla doğru orantııdır, en az 20 yıl sonra karsinojenik etkileri ortaya çıkar, bu yüzden ergen için etken demek zordur, yine de çevresel zararlı etmenleri azaltarak çocuklarımızı ilerideki kanserlerden korumalıyız.

\section{Kaynaklar}

1. Reaman GH, Bleyer WA. Infants and adolescents with cancer. In; Pizzo PA, Poplack DG ed (s). Principles and Practice of Pediatric oncology. 5th ed. Philadelphia: Lippincott Williams Wilkins, 2006: 452-75.

2. Bleyer WA, Viny A, Barr R. Cancer in 15 to 29 year-olds by primary site. Oncologist 2006; 11: 590-601. (Full Text)

3. Kutluk T, Yeşilipek A. On behalf of Turkish Pediatric Oncology Group (TPOG) and Turkish Pediatric Hematology Society (TPHD). Turkish National Pediatric Cancer Registry 2002-2008. 41st Congress of SIOP (International Society for Pediatric Oncology). 5-9 October 2009, Sao Paulo, Brazil. Pediatric Blood and Cancer 2009; 851.

4. Smith MA, Gurney JG, Ries LAG. Cancer among adolescents 15-19 years old. In: Ries LAG ed. Cancer incidence and survival among children and adolescents: United States SEER Program 1975-1995. NCl, SEER Program NIH Pub No 99-4649 Bethesda MD, 1999.

5. Stiller C. Epidemiology of cancer in adolescents. Med Pediatr Oncol 2002; 3: 149-55.

6. Bleyer WA. Cancer in older adolescents and young adults: epidemiology, diagnosis, treatment, survival and importance of clinical trials. Med Pediatr Oncol 2002; 38: 1-10. (Abstract) / (PDF) 